\title{
International perspective on mineral resources
}

\begin{abstract}
By looking at the historical use of the Earth's resources, we can recognize patterns in the mineral resources field that are still valid today. The trends of commodity prices are influenced greatly by political events, wars, and economic crises, as well as by fluctuating exchange rates. The trends of the relationship of supply and demand show that alternating times of oversupply and shortage have taken place in repeated succession.
\end{abstract}

Today, the United States, Japan, and the countries of the European Community consume between 50 and 95 percent of the total world production of mineral raw materials. As these countries become increasingly service oriented, they require less raw material to produce increasing proportions of the gross national product. If we compare this use to earlier forecasts, we see that energy and raw materials have been saved extensively during the last 15 years.

In the future, we can expect that all of the important factors relating to raw materials in the past will continue to play a role. Chief among these are the risk of war and the influence of human ingenuity. Although earth resources exist in large amounts, the demand and attainable price primarily dictate when economic use can be made of them. For long-term problems that cannot be solved effectively by market forces, we should put our trust in human ingenuity. (Ed.)

\section{Introduction}

The mineral industry is in a depressed state. The questions being asked in mineral commodity circles are as follows: How long will this slump period last? In what direction are the industries that produce and consume raw materials heading? Before analyzing the present and trying to forecast the future of mineral resources, it is essential to look back and see what has happened in the past.

\section{Historical background}

The occurrences of resources in the Earth are governed by the laws of nature, and geoscientists have done much to unravel and under- stand the natural relationships. This, however, is only the beginning; as soon as earth resources are recognized as useful commodities and are intended for exploitation, they are subjected to market forces. Earth resources can be understood fully only in the context of all the factors (geological, technological, and economic) that influence their availability. The historical background can help us to discover patterns and laws in the mineral resources field that are still valid today. We will look mainly at two aspects: the trends of both commodity prices and the relationship of supply and demand.

\section{Trends of commodity prices}

First, we must examine past price trends and the reasons for large price fluctuations (our main statistical resources are Metallgesellschaft AG and the U.S. Bureau of Mines). The market value of gold, for example, can be traced back with some confidence over two centuries (fig. 1). Gold was first valued in U.S. dollars around 1770 . Its main value is related to its uses in jewelry and as currency. Its industrial use has evolved recently. As can be seen from the graph. political events, wars, and economic crises have had considerable influence on the price curve of gold. When looking at these price curves, we need to distinguish between nominal (actual) and real prices, and in the case of gold, the official U.S. price also has to be considered. We have attempted to determine the buying power of gold by comparing it to the price of one bushel of wheat ( 60 pounds). It can be argued that agricultural productivity has risen markedly over the last few decades and has caused food to become relatively cheaper. However, when the wheat index is compared with the deflated gold price since 1790, a certain degree of parallelism becomes obvious, which suggests that the wheat index is well suited to be a trend indicator. We see that between 1800 and 1880 the buying power of gold remained relatively constant. It reached a peak around the turn of the 20th century and another peak during the worldwide economic crisis in the twenties, and we are witnessing a third peak now that the price of gold has been decontrolled. In Canada, there is an old miner's saying that the gold price is right when 1 ounce (oz) of gold will buy a man's suit. According to this rule, the price was right in 1935 at US\$35/oz and is again today at US\$300-400/oz. In the $1950 \mathrm{~s}$ and $1960 \mathrm{~s}$, when the price was fixed at US $\$ 35 / \mathrm{oz}$, gold was decidedly too cheap.

Typical examples of metal price trends in terms of nominal and deflated real prices from 1900 until today are shown in figures 2 through 5, where they are related to important political and economic events. Copper prices in real terms have had a falling trend since 1900, whereas the price of zinc generally has kept level (fig. 2). The real price of aluminum (fig. 3) has been practically constant since 1950 , when the consumption of aluminum started to rise steeply. The curve for tin (fig. 4) shows that the International Tin Agreements managed to raise the real price of tin up to the time of the collapse of the International Tin Council in 1985, but as will be shown later, this had a significant impact upon consumption. Figure 5 demonstrates that the prices for tungsten and nickel, examples of steel-related metals, are much influenced by wars. The price trends of all these examples show that political and economic events are very important factors in influencing metal prices.

With regard to the actual monetary value of raw materials, fluctuating exchange rates have a major influence as well. Mines in 


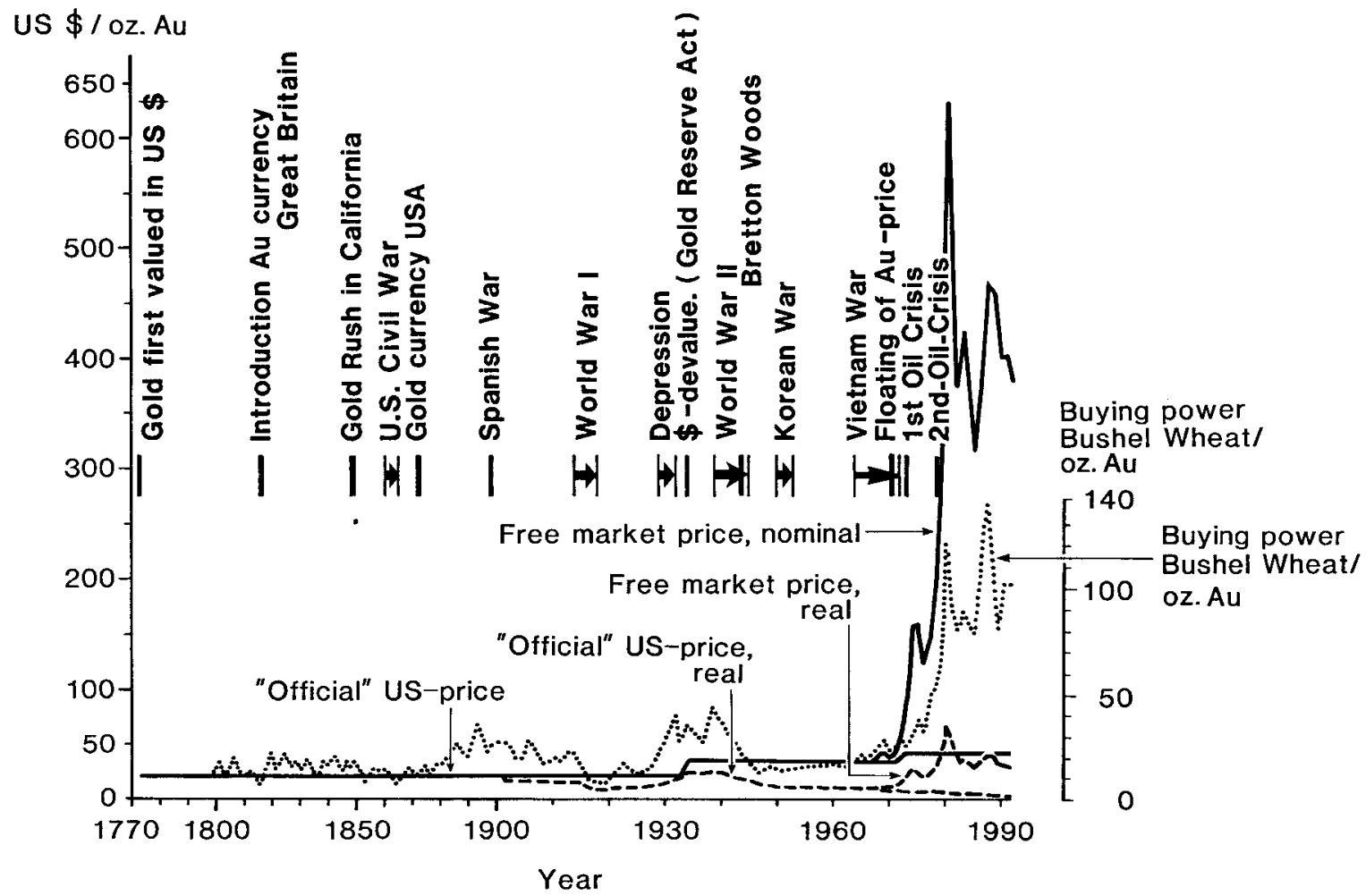

Figure 1. -Gold ( $\mathrm{Au}$ ) prices (US\$) in real and nominal terms compared with major historical events. Also, the relationship of the price of gold to the price of wheat (US\$/60-pound bushel).

countries having hard currencies that generally tend to appreciate against the U.S. dollar as the lead currency in commodity markets face the prospect of declining revenues in their own currency, even if the commodity prices in U.S. dollars keep level in real terms. In several cases in various countries, mines have had to close because of the appreciation of their operating currency. Figure 6 shows the trends in lead and zinc prices in U.S. dollars and in German marks, which clearly illustrate the effect of the stronger German currency since 1970 .

\section{Trends of the relationship of supply and demand}

A second aspect to examine for historical background is the supply and demand situation. The consumption of raw materials has risen impressively since the end of World War II. During this time span, more mineral resources have been consumed than have been in the whole previous history of man. The United States, Japan, and the countries of the European Community consume by far the largest share of all the mineral resources that are produced and processed in the Western World.

If one compares production and consumption curves from the turn of the century until today, a period covering two World Wars and two oil crises, one can see how times of oversupply and shortage have taken place in repeated succession. Aluminum is given as an example in figure 7 . The ups and downs in metal production and consumption have become larger during the last decade, and the cycles follow each other more rapidly. Production and consumption curves for aluminum, zinc, and copper are given in figure 8 for the period since 1970. The curves for aluminum, in particular, show the extremely difficult situation in which the metal industry finds itself.
Since the first oil crisis, the production and consumption curves have diverged strongly. Why? The previous high rates of growth of consumption were simply extrapolated, and as consumption fell, overcapacities developed. As a result, smelters could not operate on full capacity, and some even had to close. As soon as consumption increased and became level with production again, additional production capacity was added in the vain hope that the previous high growth rates in consumption would return. However, a consumption plateau had been reached, and as a result, another period of overproduction began, so that the cycle started anew.

The curves in figures 7 and 8 provide us with additional information. The annual rates of growth of production for metals during the decade 1950-1960 were mostly larger than those between 1960 and 1970, and these in turn were larger than those during the time span 1970-1990. The time needed to reach the next highest level of production became increasingly longer. This general pattern is similar for many mineral raw materials: a steep rise in consumption is followed by a slow rise and then by a level or a nearly level period. In general, we can state that today the highly developed economies have reached a state of saturation (Humphreys, 1982). A near-plateau situation was reached in the period 1975-1985.

With regard to future demand, the following hypothesis is worth considering. Each individual raw material reaches a specific consumption plateau on which, over a relatively long period of time, perhaps on the order of 10 years, demand varies within rather narrow limits (Sames, 1986). Steel and base metals, excluding aluminum, appear to have reached such a plateau. Only after a lengthy period of time do new factors begin to restimulate the consumption of certain metals, and then consumption rises until the next plateau is reached. The plateau hypothesis, therefore, certainly is not incompatible with growth. 


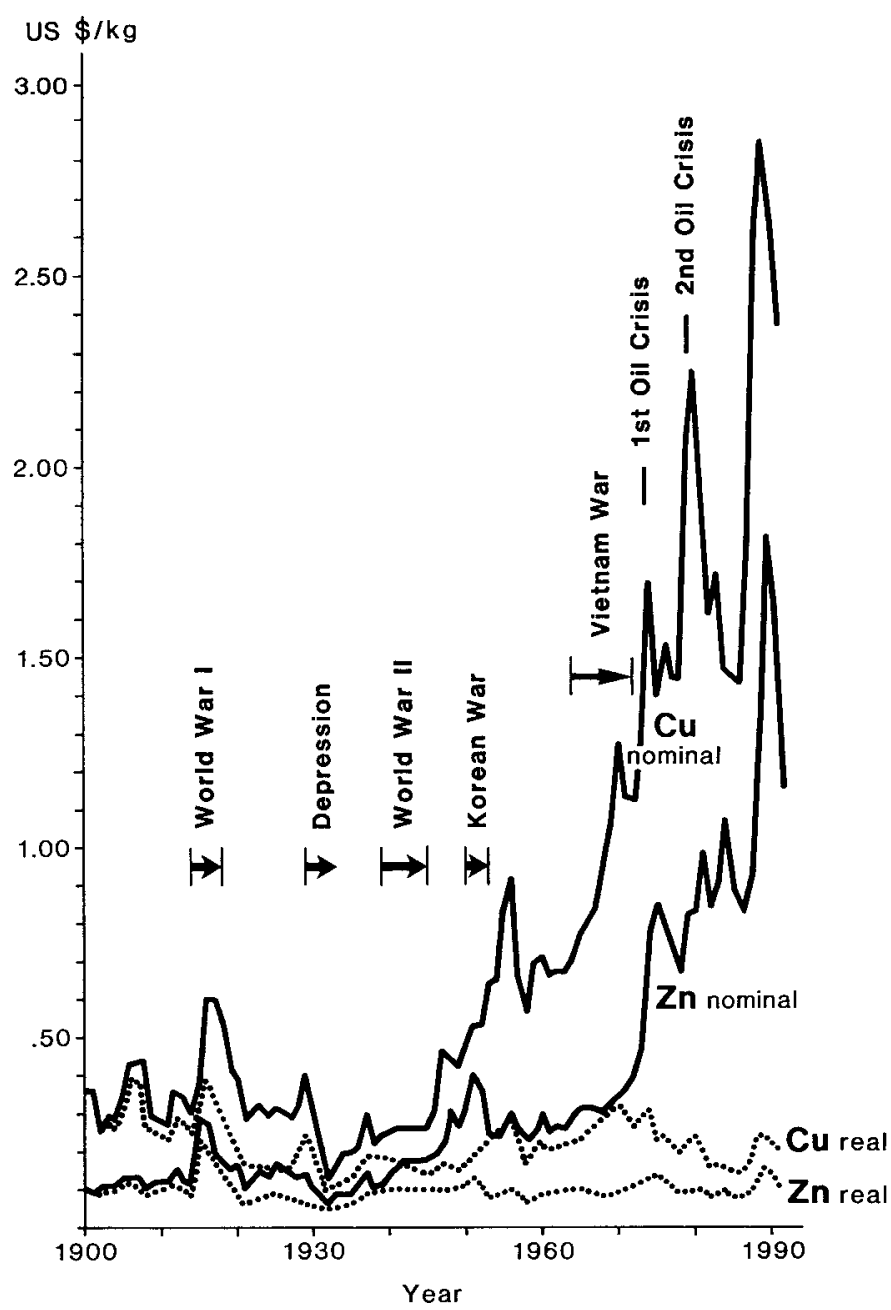

Figure 2.-Prices (US\$) for copper (Cu) and zinc ( $\mathrm{Zn})$ in real and nominal terms compared with major historical events.

The following observations tend to substantiate the above hypothesis:

- The general cyclicity that exists for the growth rates of the overall economy worldwide. Even in a plateau situation, a certain relationship still remains between the trend of the gross national product (GNP) and raw materials consumption. This has been studied in detail for the German steel industry. It was shown that for growth rates of the GNP up to 2.5 percent, steel consumption decreases or stagnates, but for a GNP growth of 3.5 percent, steel consumption increases by 1.5 percent (RWI, 1985).

- The rapid growth of consumption that takes place in the newly industrialized countries (NICs) as new, major consumption centers. The consumption of base metals (for example, aluminum, copper, zinc, and lead) in the less developed countries ranges between 12 and 25 percent of world consumption, whereby the main centers of consumption are the NICs and the countries having large populations. Figure 9 shows how the centers of metal consumption changed between 1950 and 1990 and how metal consumption grew disproportionately in comparison to the population increase in the less developed part of the world. Figure $10 \mathrm{com}-$

Figure 4. -Price (US\$) for tin (Sn) in real and nominal terms compared with major historical events.

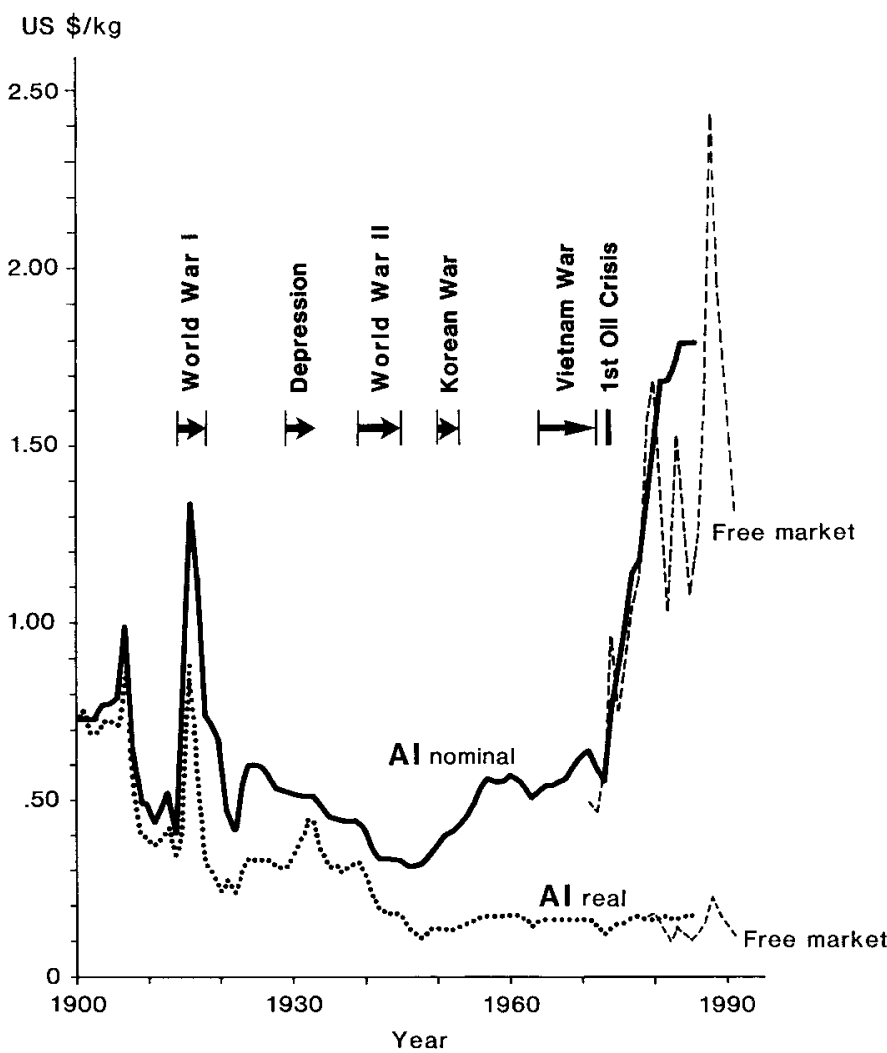

Figure 3. - Price (US\$) for aluminum (Al) in real and nominal terms compared with major historical events.

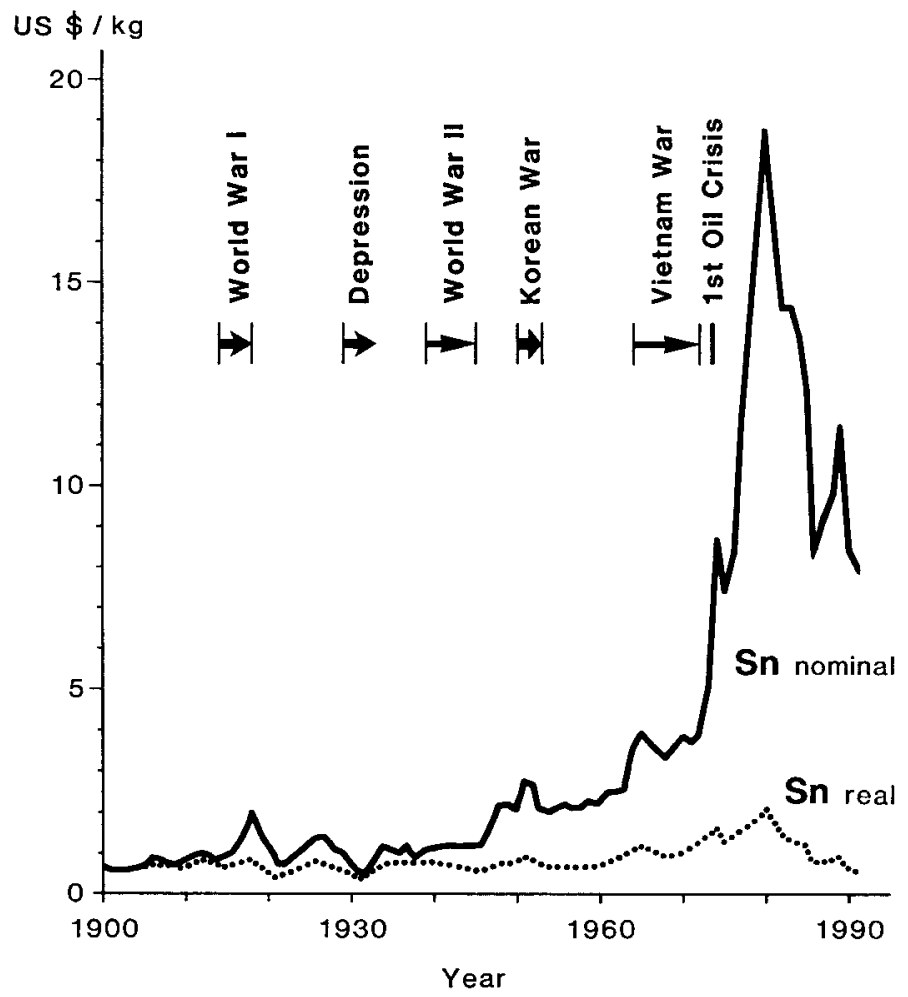




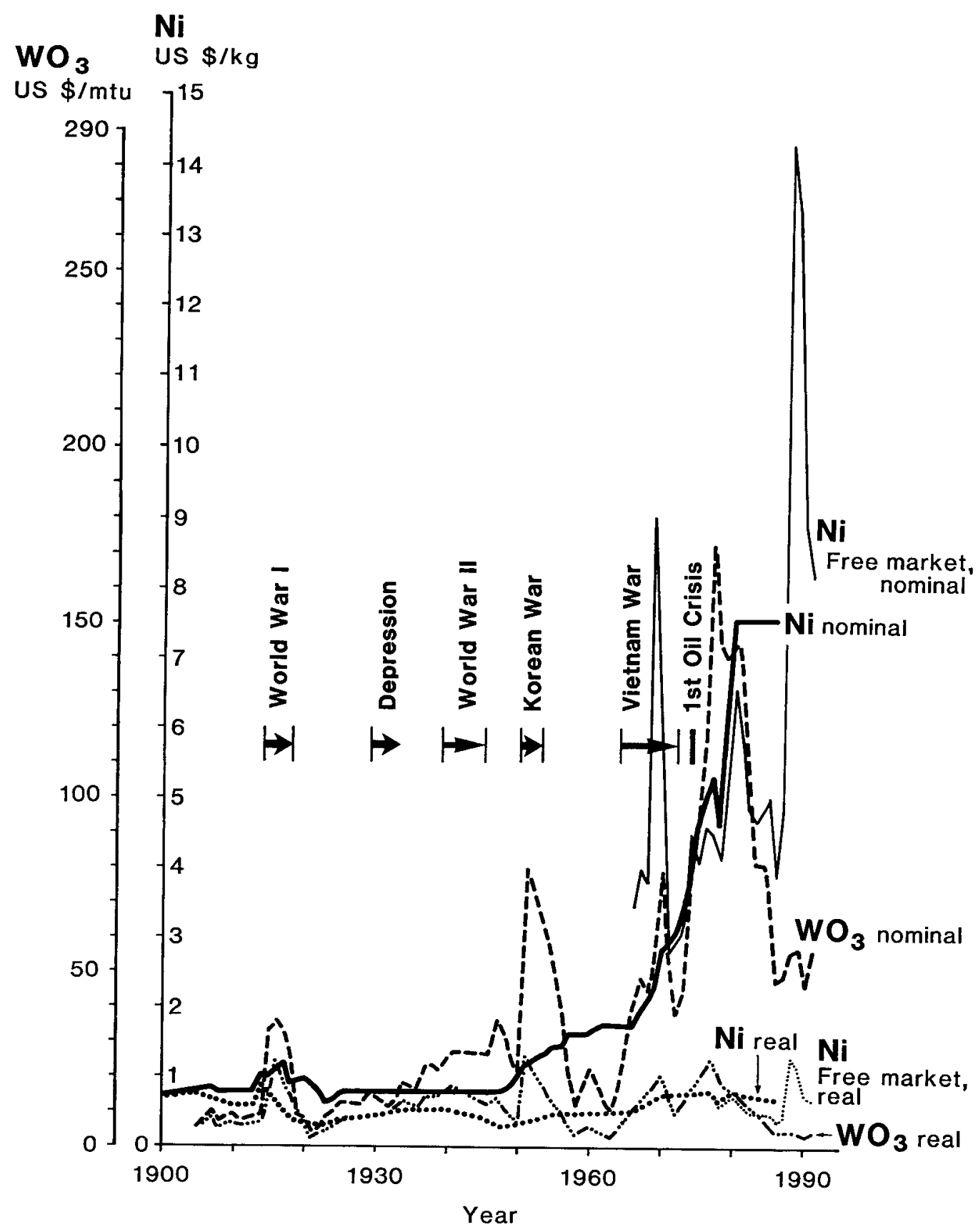

Figure 5.-Prices (US\$) for tungsten (W) and nickel (Ni) in real and nominal terms compared with major historical events. Abbreviation: mtu, metric ton unit.

pares the base metal consumption per capita in the industrialized Western nations with those of the NICs of Taiwan and the Republic of Korea.

- The continuous decline in real prices of certain metals (see, for example, copper in figure 2) could result in increased use and thus a "renaissance" of these metals. Tin is a good example: the drastic fall of the tin price to a lower, more realistic market level at the collapse of the International Tin Council in 1985 was followed by a growth in consumption of 3.2 percent per year on average between 1985 and 1990. The growth was in strong contrast to the stagnant consumption or even declining pattern during the previ- ous high-price period (fig. 11). This was followed, after a time delay of 3 years to reduce stocks, by an increase in primary production.

\section{The present situation}

Within the western World, the United States, the countries of the European Community, and Japan consume between 50 and 95 percent of the total world production of mineral raw materials, depend- 


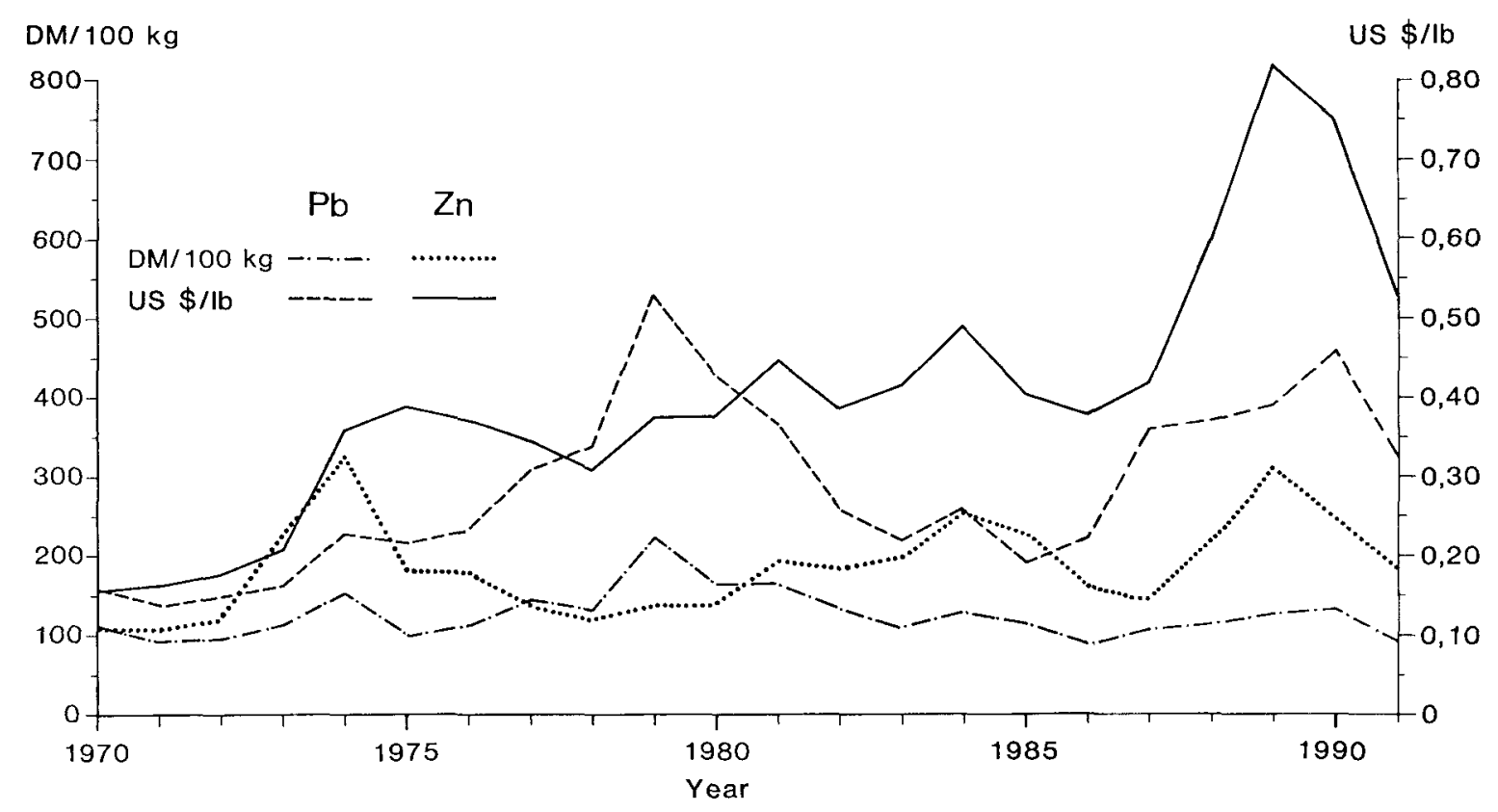

Figure 6. - Prices for lead (Pb) and zinc in U.S. dollars and German deutsche marks (DM).

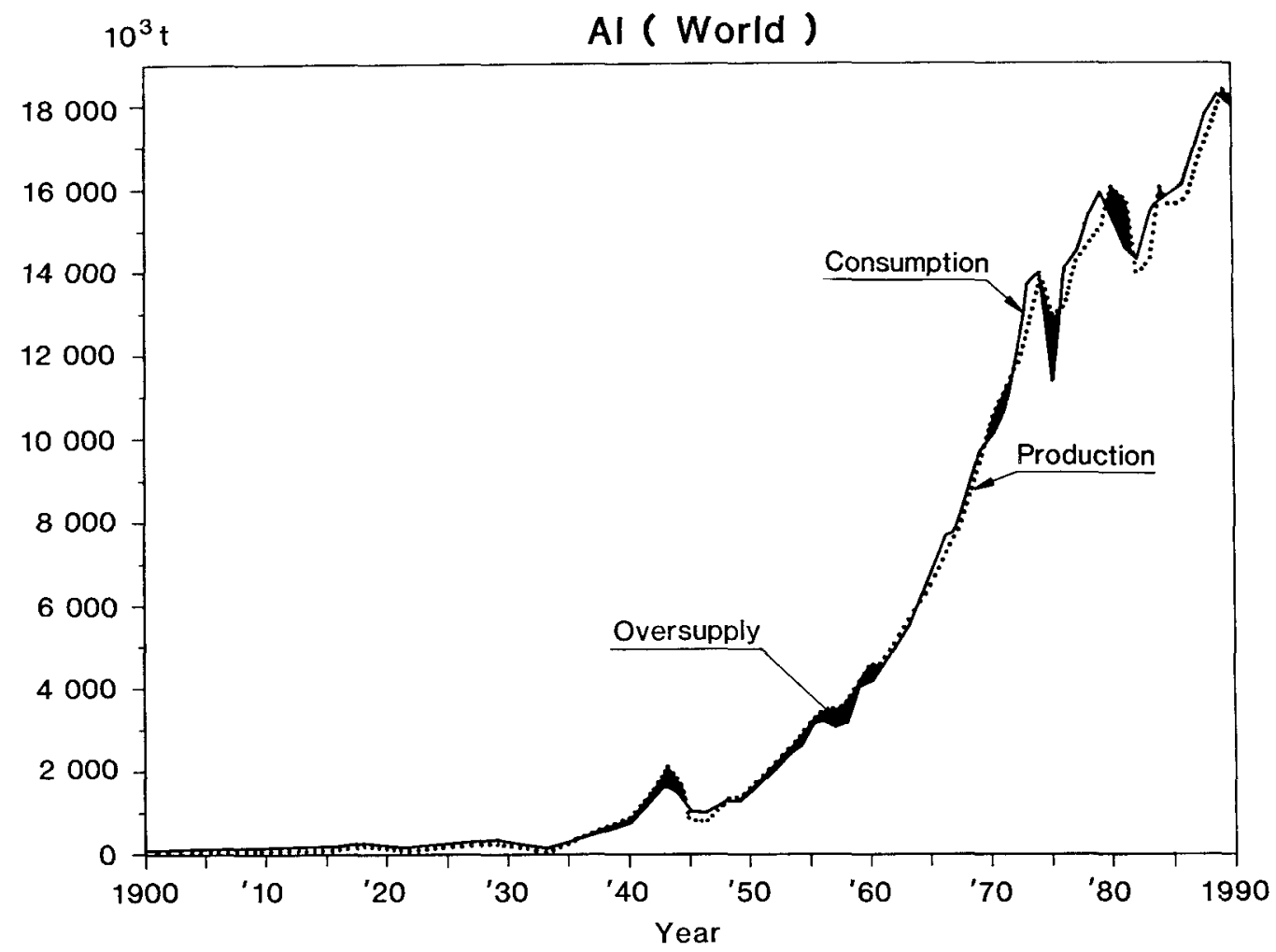

Figure 7.-Production and consumption of aluminum since 1900. 
ing on the individual commodity. These societies are becoming increasingly service oriented, which means that increasing proportions of the gross national products are produced with only a minimal input of raw materials.

A most instructive way to analyze consumption trends is by considering the concept of "intensity of use" (Malenbaum, 1978). This factor relates metal consumption to gross national product. Intensity of use curves have been constructed for several metals, and when these curves are compared with earlier forecasts, it becomes apparent how extensively metals, such as aluminum, have been saved during the last 15 years (fig. 12).

The saving of energy and raw materials is a keyword in the field of earth resources. A few examples serve to illustrate the volume of
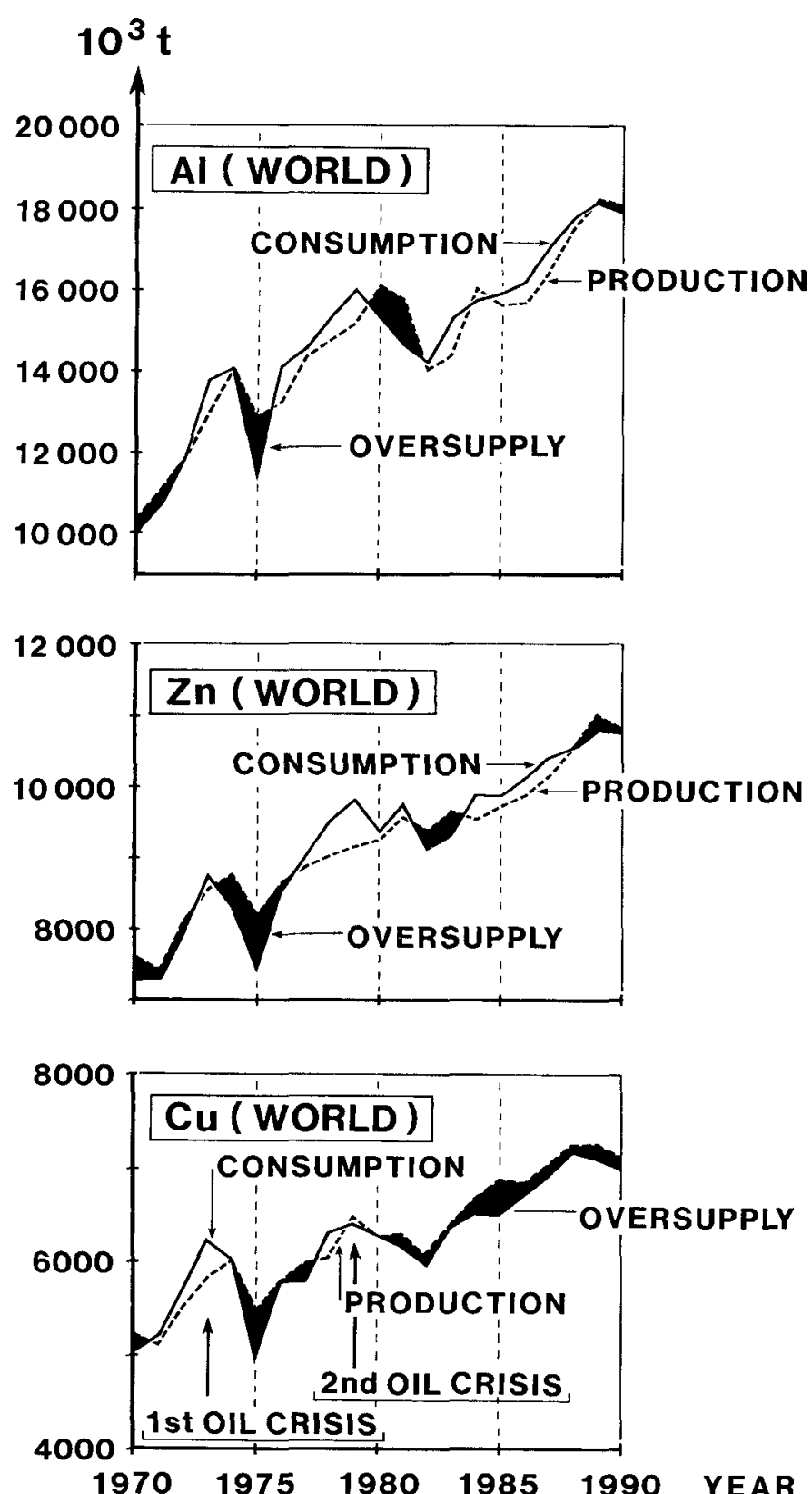

Figure 8.-Production and consumption of aluminum, zinc, and copper since 1970. savings that can be achieved. In Germany, the Federal postal service is the main user of copper wire, but recently, it was decided to substitute glass fiber for copper in the telephone and telecommunication network. Just between 1988 and 1991, this program has led to savings of up to approximately 200,000 metric tons ( $t$ ) each year, which corresponds to about 18 percent of Germany's total annual consumption of copper (table 1).

Another method of saving is recycling. Significant progress has been made in this field during recent years. For several metals, the recycling rate already is as much at $40-50$ percent of the annual production. This figure, of course, cannot be generalized, and specific conditions have to be met in each case. Nevertheless, a very large, potential saving of the Earth's resources can be achieved by recycling.

In addition to the production and consumption trends and the substitution and recycling of materials, energy conservation is of prime importance, particularly with regard to processing costs. Aluminum is one of the most intensely energy-consuming metals to process. Consequently, great efforts have been made to reduce the specific energy consumption involved in aluminum processing (fig. 13). As a general indicator of the cost of energy, the oil price has been inserted into the diagram. Another example is the relative cost of energy used for nickel processing in relation to the nickel price since 1966 (fig. 14). Because nickel production from lateritic ores consumes much more energy than production from sulfide ores does, energy costs influence the kind of nickel ore that is preferred for nickel production (table 2 ). The ratio of laterite to sulfide ore reached

Table 1.-Installation of glass fiber instead of copper wire for telecommunication system in the Federal Republic of Germany [Source: Telekom, Germany, written communication, 1992]

\begin{tabular}{lccc}
\hline Installed glass fiber & $\begin{array}{c}\text { Substitution } \\
\text { of Cu }\end{array}$ & $\begin{array}{c}\text { Substitution } \\
\text { as percentage } \\
\text { of German total } \\
\text { Cu consumption }\end{array}$ \\
\hline 1989 & $141,885 \mathrm{~km}$ & $\sim 107,000 \mathrm{t}$ & $\sim 9$ \\
1990 & $278,670 \mathrm{~km}$ & $\sim 210,000 \mathrm{t}$ & $\sim 18$ \\
1991 & $268,981 \mathrm{~km}$ & $\sim 200,000 \mathrm{t}$ & $\sim 18$
\end{tabular}

Table 2,-Percentage of world mine production of nickel from sulfide and laterite ores, 1950-1990 (selected years)

\begin{tabular}{cccc}
\hline & Sulfide ores & $\begin{array}{c}\text { Laterite } \\
\text { ores }\end{array}$ & $\begin{array}{c}\text { Laterite/sulfide } \\
\text { ratio }\end{array}$ \\
\hline 1950 & 86 & 14 & 0.16 \\
1955 & 77 & 23 & .31 \\
1960 & 71 & 29 & .41 \\
1965 & 71 & 29 & .42 \\
1970 & 64 & 36 & .57 \\
1975 & 61 & 39 & .64 \\
1980 & 59 & 41 & .71 \\
\hline 1981 & 58 & 42 & .72 \\
1982 & 59 & 41 & .71 \\
1983 & 61 & 39 & .64 \\
1984 & 62 & 38 & .62 \\
1985 & 60 & 40 & .65 \\
1986 & 62 & 38 & .62 \\
1987 & 64 & 36 & .56 \\
1988 & 64 & 36 & .56 \\
1989 & 62 & 38 & .62 \\
1990 & 63 & 37 & .59 \\
\hline
\end{tabular}


Figure 9.-Distribution of population and distribution of metal consumption in 1950 and 1990 compared between developing and developed regions. Numbers given are percentages.

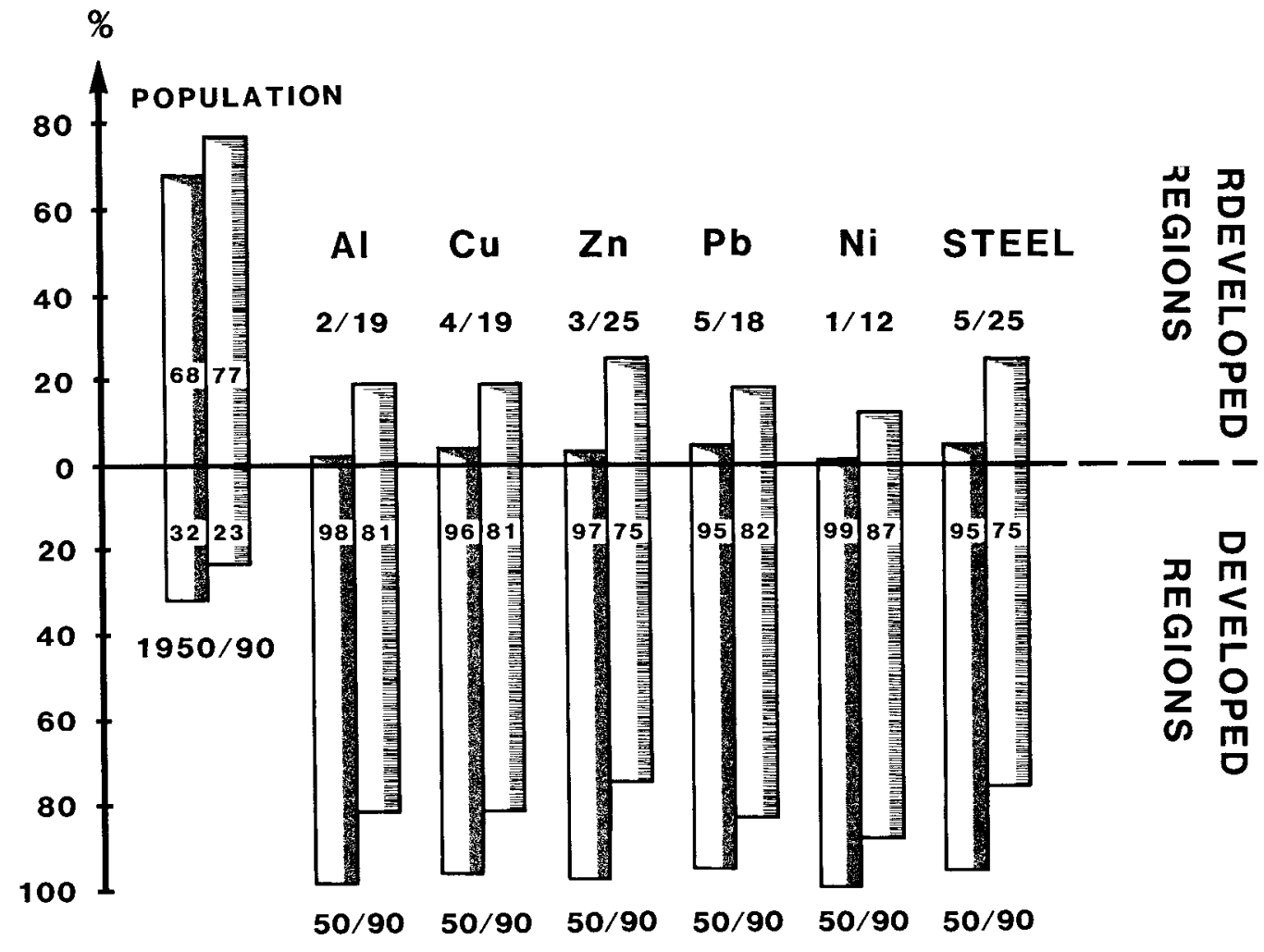

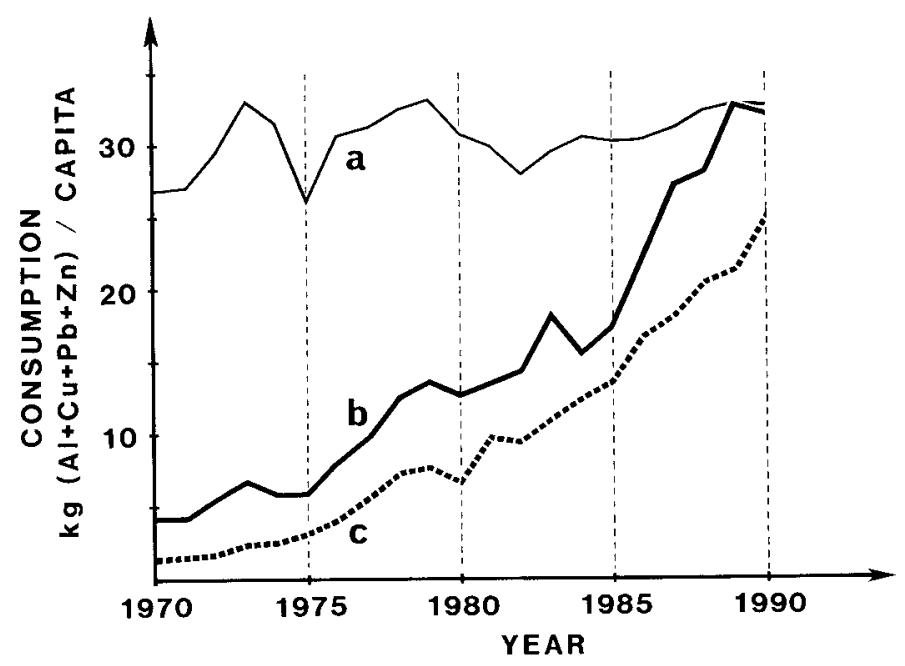

Figure 10. - Development of base metal consumption $(\mathrm{Al}, \mathrm{Cu}, \mathrm{Pb}$, $\mathrm{Zn}$ ) per capita in industrialized countries (a) and in the nearly industrialized countries of Taiwan (b) and the Republic of Korea (c) from 1970 to 1990.

a peak in 1980-1982. As a result of the high rate of investment over the last few years, especially in the fixed costs in laterite-processing plants, the proportion of laterite ore is not expected to decline rapidly; it is more likely that it will stay more or less level and then will fall slowly.

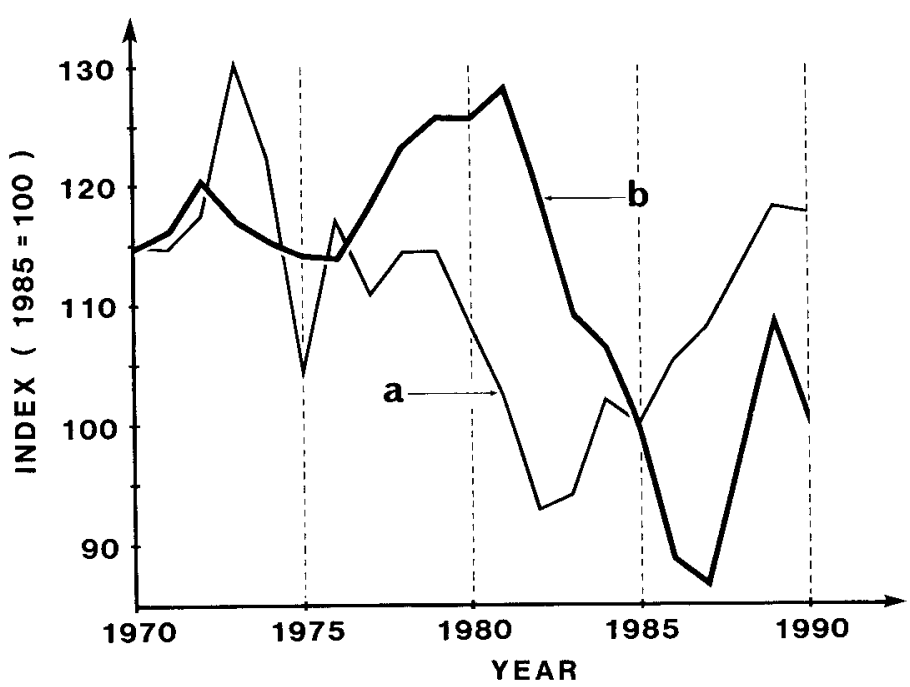

Figure 11.-Relative development of tin consumption (a) and mining production (b) in the Western World from 1970 to 1990 (index $1985=100)$.

As is evident in the price graphs (figs. 1-5), political factors, especially wars, have a very strong influence on price trends. Today, we have to consider quite a number of additional political factors that affect the raw materials situation. These factors include development in the Third World, disparities in worldwide population growth, 


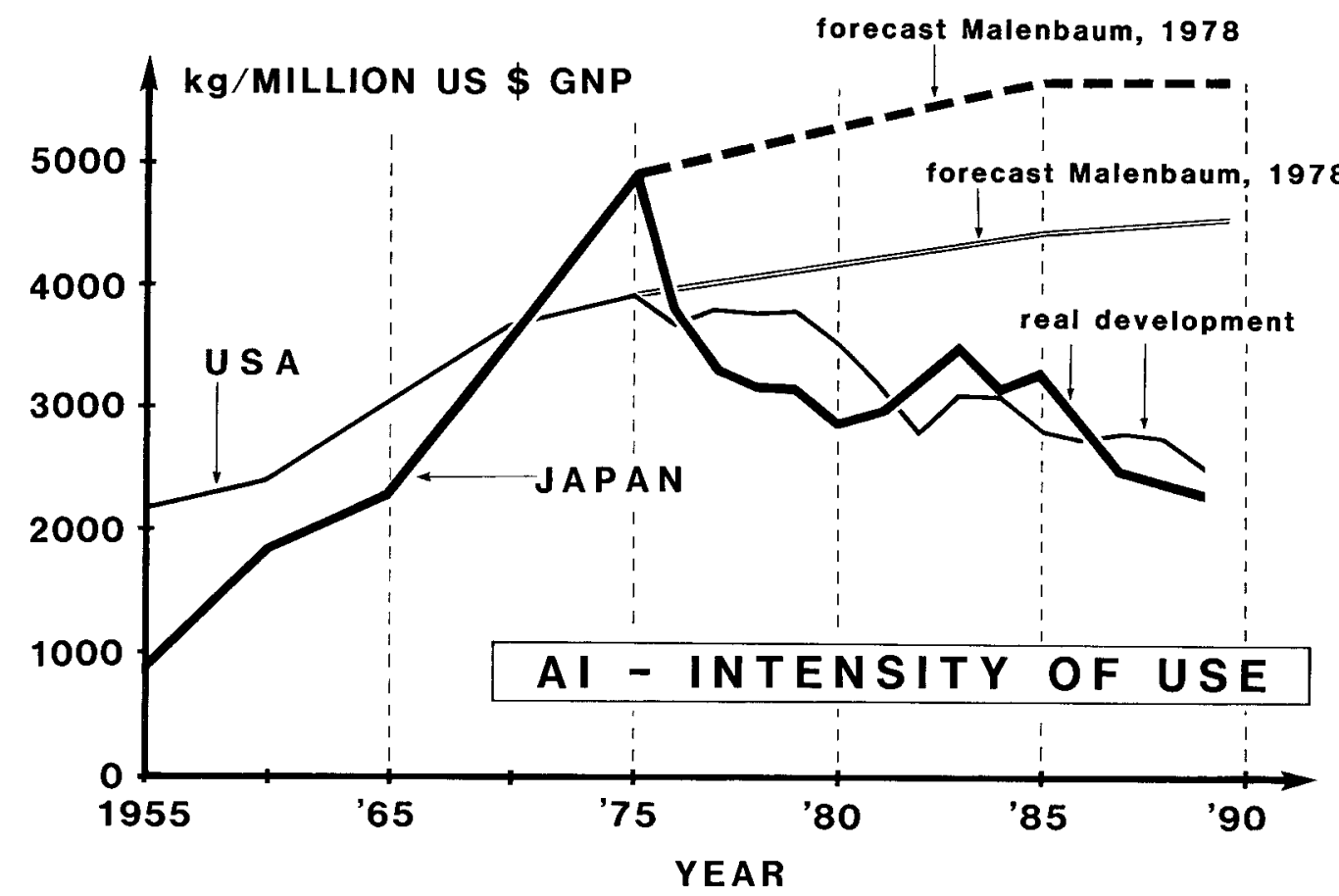

Figure 12.-Comparison of the forecast of Malenbaum (1978) with the real development of the "intensity of use" factors of aluminum for the USA and Japan. Abbreviation: GNP, gross national product.

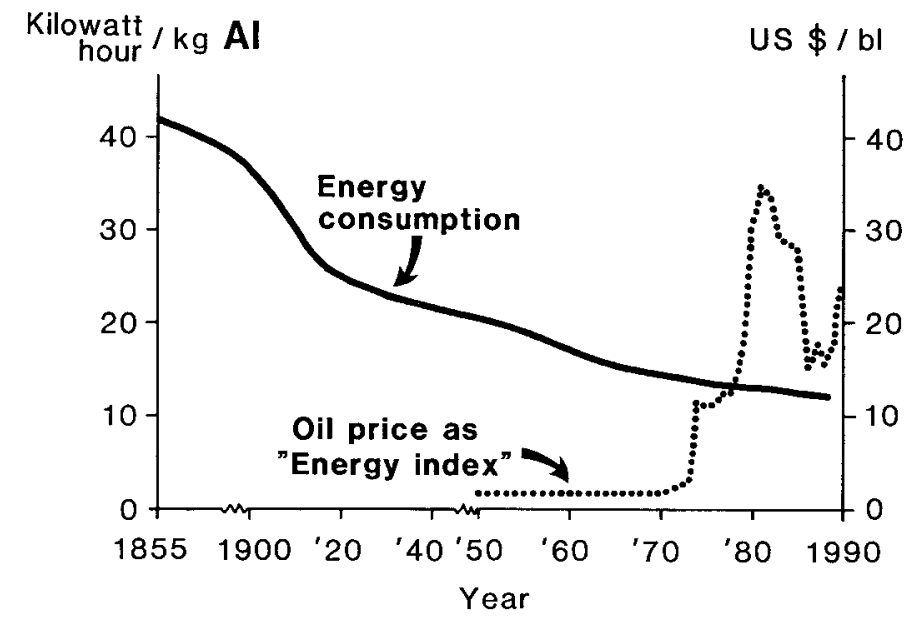

Figure 13. - Time trends for the energy consumption per unit of aluminum production and for the oil price. Abbreviation: bl, barrels.

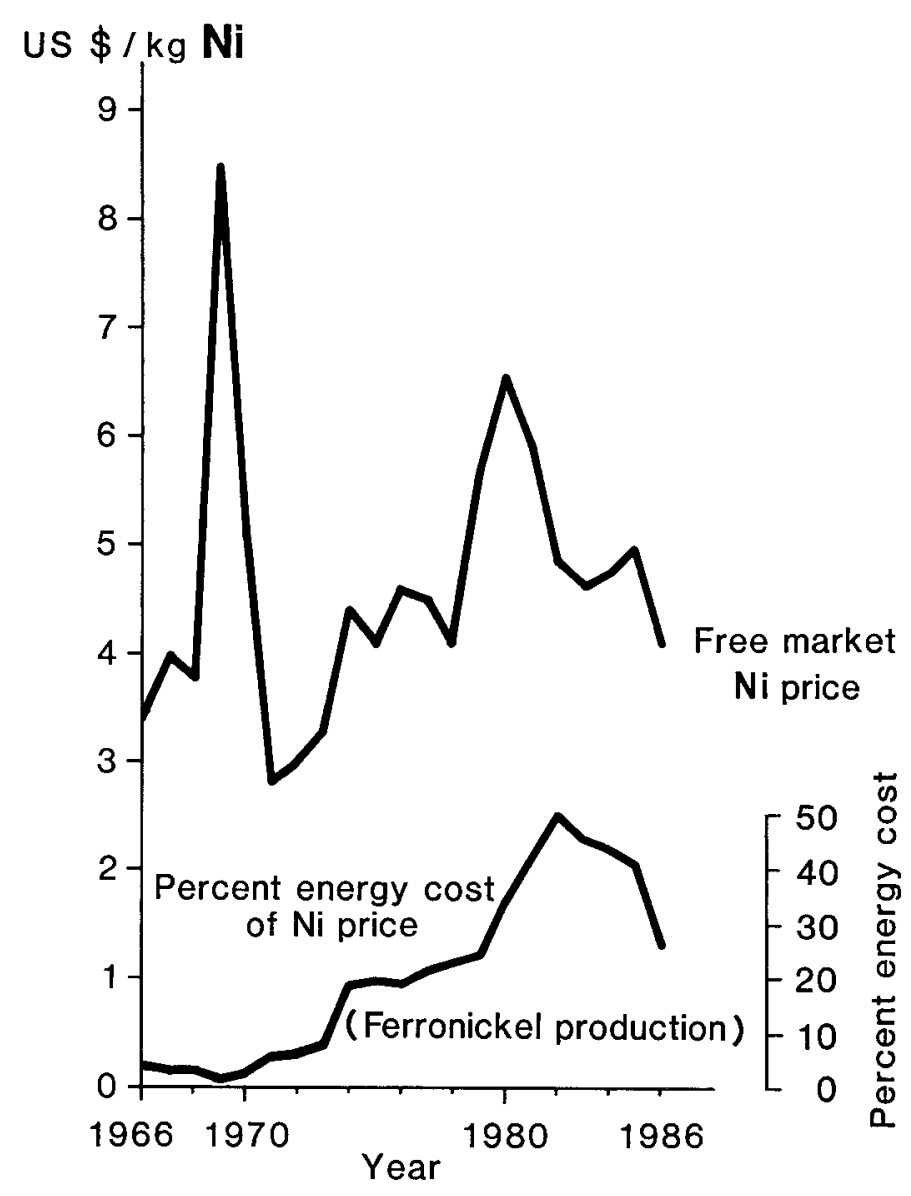

Figure 14.-Time trends of free market nickel price and of the relative energy cost for the production of ferronickel as a percentage of the nickel price. 


\section{Steel production (world),}

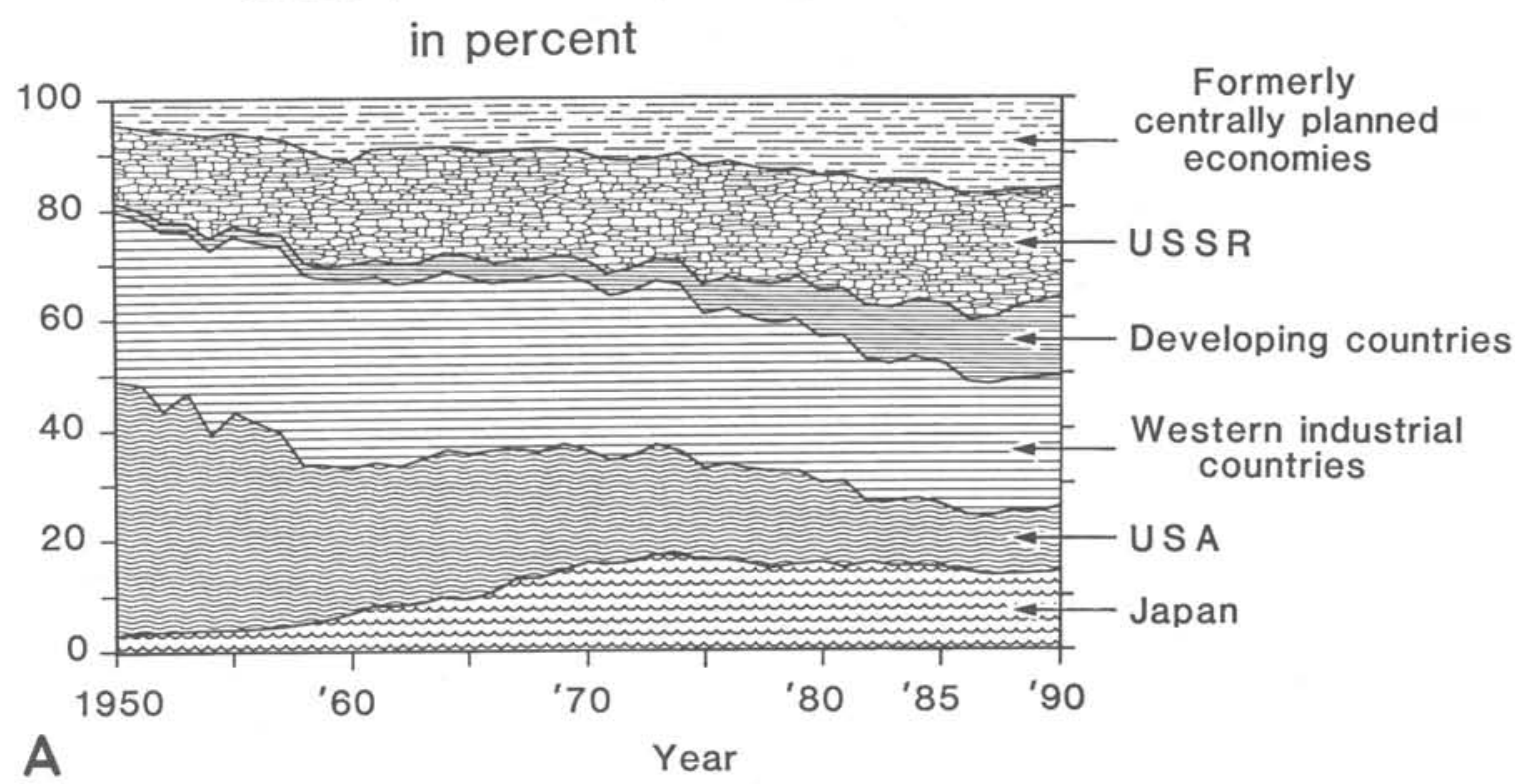

\section{Sn - smelter production (world), in percent}

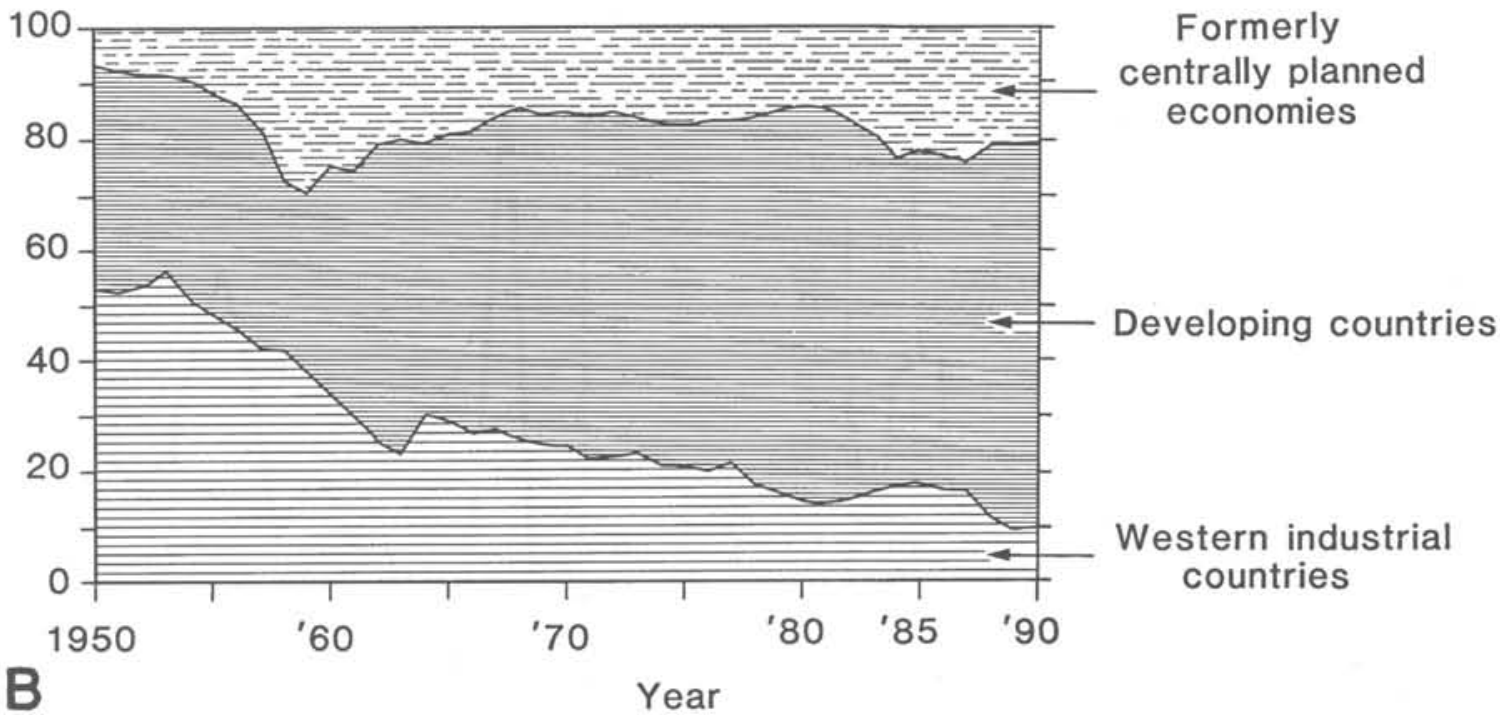

Figure 15.-Development of the share of production of steel (A) and of smelted tin (B) in the major economic regions of the world from 1950 to 1990.

environmental awareness and restrictions, regional differences in the distribution of resources, and to some extent, ideological differences. Mine production and smelter capacities have changed significantly over the last 35 years. Since 1950, the world has witnessed a drastic relative decrease in the United States' production of steel (fig. 15A), zinc, copper, and aluminum. Steel, nickel, and especially tin (fig. 15B) show a significant increase in production in the developing countries. Disparities between population distribution and shares of raw materials consumption are particularly impressive (fig. 9). We anticipate that, directly or indirectly, the factor of disparity in popu- lation growth will prove to be a major influence on worldwide supply and demand patterns.

Another problem in the market for raw materials is the political regulation of trade: protectionism. Protectionism caused Japan to become the world's largest importer of copper ores and concentrates (fig. 16). Without wishing to deny individual countries their sovereign rights, the authors feel that protectionism, of whatever kind, produces more severe problems in the long run by disturbing the functioning of an open, multilateral trading system for the benefit of all nations than it seems to solve in the short-term perspective. 


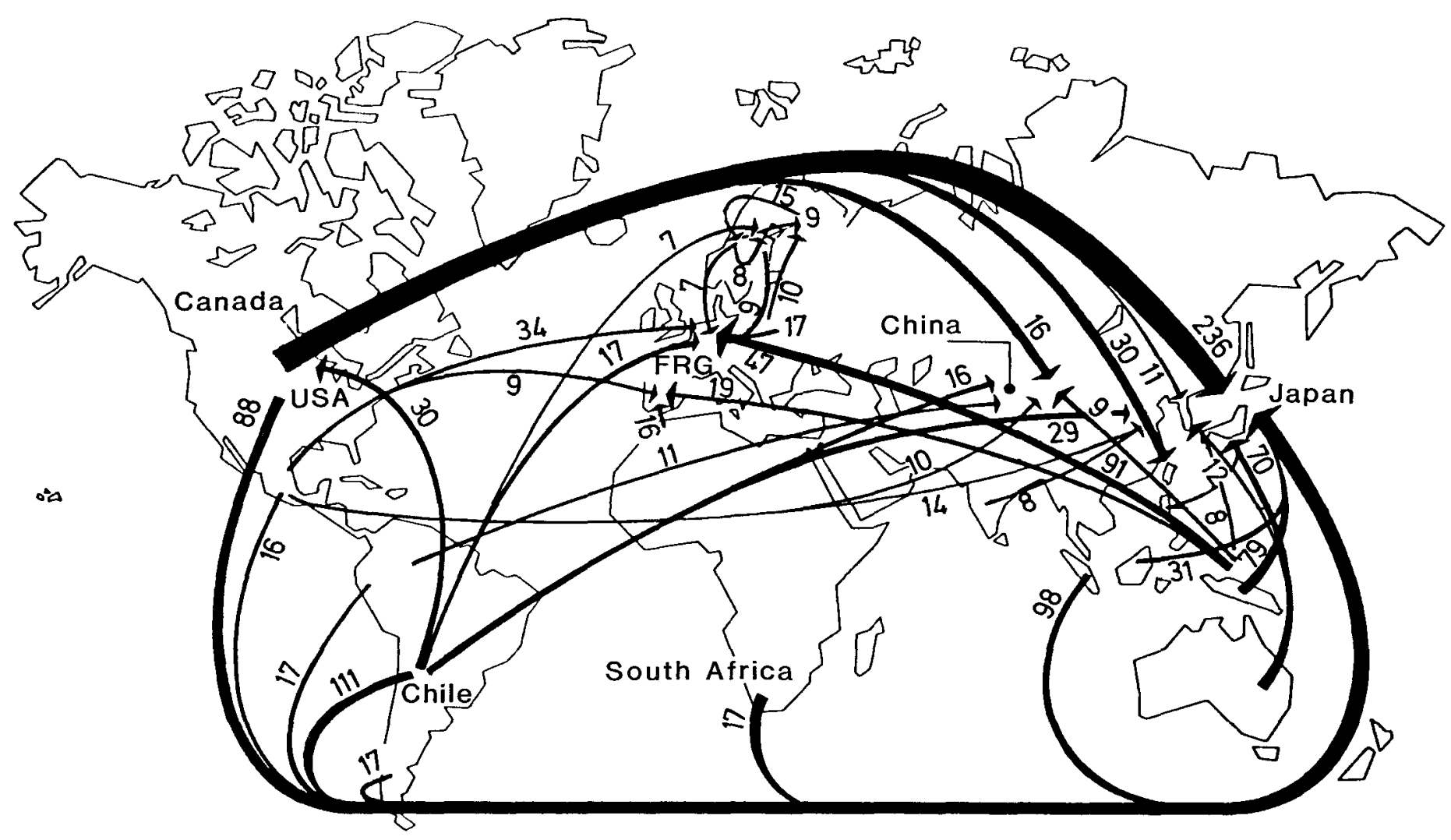

Figure 16. - Major trade flow of copper ores and concentrates in 1985. Copper content is given in 1,000 $t$ (source: Metallgesellschaft AG, Frankfurt, written communication, 1987).

In fact, any kind of political interference with the free flow of raw materials has the potential of distorting the market considerably. This applies particularly to commodities that have a high regional concentration, such as the steel-alloy metals and platinum-group metals (table 3 ), which are considered both sensitive and strategic.

\section{Future outlook}

A number of individual factors influencing the supply and demand situation and the price patterns of mineral resources have been examined. What does this mean for the future?

Basically, one can expect that all of these factors that have played a role in the past will continue to do so. In looking at the future of earth resources and their uses, we feel that attention should be focused on the following important factors:

- The risk of war will always be a factor.

- The influence of human ingenuity will stimulate technical developments and will result in structural changes in the technical sector.

- Disparities in worldwide population growth and the development of the Third World may lead to changes in the pattern of economic power.

- Changes in consumer behavior will produce new demand patterns.

- Environmental restrictions will influence prices and markets.
The first two factors are considered to be the most important ones. War is an incalculable risk, the avoidance of which should be everyone's concern. Scientists themselves can contribute toward the lessening of tension through international cooperative research. Even commerce and trade are useful instruments in promoting international understanding and, hence, in reducing tension.

Concerning human ingenuity, the authors share an optimistic view. History has shown that the human mind is able to look ahead to invent new products and processes when it is profitable or when the need for them arises. For example, the severe cobalt crisis at the end of the 1970s led to the development of new alloys, and it finally resulted in a drop in the cobalt consumption in Germany from 2,400 to 1,700 t (BGR/DIW/ITE, 1986). McKelvey (1972) described the effects of raw material supply and ingenuity on our standard of living with the following semiquantitative expression:

$$
\mathrm{L}=\frac{\mathrm{R} \times \mathrm{E} \times \mathrm{I}}{\mathrm{P}} \text {. }
$$

where $\mathrm{L}$ is society's average standard of living (measured in terms of its consumption of goods and services), $R$ is its consumption of all kinds of raw materials (including metals, nonmetals, water, soil, minerals, and biological products), $E$ is its energy consumption, $I$ is its consumption of all forms of ingenuity (including political and socioeconomic, as well as technological, ingenuity), and $P$ is the number of people sharing these benefits. 
Table 3. - World reserves (proven and probable) for the year 1991-1992

[PGM, platinum-group metals; boxed, high regional concentration; -, not significant]

\begin{tabular}{|c|c|c|c|c|c|c|c|c|}
\hline Raw material & $1,000 \mathrm{t}$ & $\begin{array}{c}\text { Western Europe } \\
\%\end{array}$ & $\begin{array}{c}\text { USA, Canada } \\
\%\end{array}$ & $\begin{array}{c}\text { Latin America } \\
\%\end{array}$ & $\begin{array}{c}\text { Africa } \\
\%\end{array}$ & Asia & $\begin{array}{c}\text { Australia, } \\
\text { Oceania } \\
\%\end{array}$ & $\begin{array}{c}\text { Previously } \\
\text { centrally planned } \\
\text { economies } \\
\%\end{array}$ \\
\hline Bauxite & $22,983,000$ & 3 & 0 & 28 & 30 & 8 & 24 & 5 \\
\hline Copper & 327,700 & 2 & 20 & 37 & 13 & 7 & 4 & 18 \\
\hline Lead & 70,100 & 9 & 27 & 8 & 7 & 3 & 15 & 31 \\
\hline Zinc & 149,100 & 11 & 28 & 13 & 9 & 10 & 12 & 17 \\
\hline Tin & 4,790 & 4 & 2 & 29 & 3 & 44 & 3 & 16 \\
\hline Iron & $68,880,000$ & 4 & 12 & 17 & 5 & 7 & 15 & 40 \\
\hline Chromite & $1,363,000$ & 3 & - & 1 & 81 & 5 & 0 & 10 \\
\hline Manganese & 814,700 & - & - & 3 & 52 & 2 & 5 & 38 \\
\hline Cobalt & 2,785 & 1 & 2 & 7 & 63 & 12 & 9 & 7 \\
\hline Molybdenum & 5,645 & - & 56 & 24 & - & 1 & - & 18 \\
\hline Nickel & 35,659 & 2 & 17 & 22 & 9 & 10 & 19 & 22 \\
\hline Niobium & 5,017 & - & 3 & 82 & 2 & 0 & - & 14 \\
\hline Tantalum & 23 & - & 8 & 4 & 16 & 36 & 20 & 13 \\
\hline Vanadium & 7,587 & 2 & 2 & 0 & 53 & 0 & 1 & 43 \\
\hline Tungsten & 2,355 & 6 & 17 & 4 & 0 & 5 & 2 & 61 \\
\hline Ilmenite (as $\mathrm{TiO}_{2}$ ) & 210,800 & 16 & 17 & 1 & 20 & 18 & 11 & 17 \\
\hline Rutile (as $\mathrm{TiO}_{2}$ ) & 23,930 & - & 1 & 0 & 27 & 22 & 38 & 11 \\
\hline Zircon (as $\mathrm{ZrO}_{2}$ ) & 28,000 & 1 & 11 & 4 & 18 & 10 & 42 & 14 \\
\hline Lithium & 1,417 & 0 & 21 & 52 & 2 & - & 11 & 14 \\
\hline Rare earth & 64,885 & - & 21 & 0 & 0 & 4 & 8 & 67 \\
\hline Gold & 39 & 0 & 17 & 6 & 48 & 3 & 7 & 19 \\
\hline PGM & 37 & - & 1 & - & 82 & - & 0 & 16 \\
\hline Silver & 247 & 6 & 28 & 29 & 4 & 3 & 9 & 23 \\
\hline Asbestos & 113,900 & 4 & 39 & 5 & 12 & 1 & 2 & 38 \\
\hline Fluorspar & 208,400 & 13 & 3 & 11 & 18 & 3 & 0 & 53 \\
\hline Potash & $9,516,000$ & 8 & 47 & 1 & - & 1 & - & 43 \\
\hline Phosphate & $8,775,600$ & 0 & 20 & 6 & 57 & 6 & 0 & 11 \\
\hline
\end{tabular}

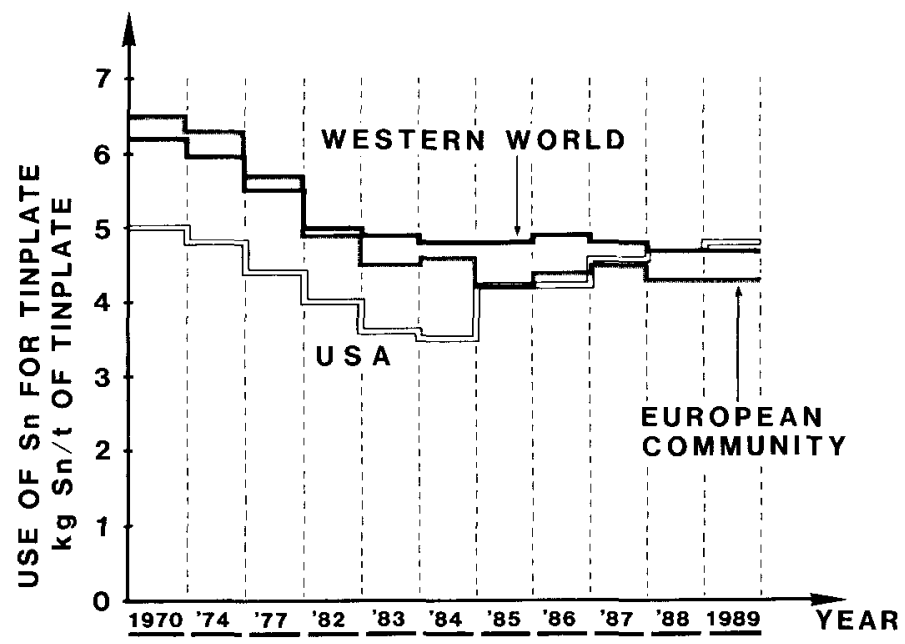

Figure 17. - Use of tin in tinplate manufacture for selected years (sources: World Tin, 1990; The Economist Intelligence Unit, 1992).
Three additional examples might illustrate the role of human ingenuity:

- The development of improved processing techniques led to a reduction in the specific consumption of tin for tinplate, the major use of tin in the Western World, from $6.2 \mathrm{~kg} \mathrm{Sn} / \mathrm{t}$ of tinplate in 1970 to $4.8 \mathrm{~kg} \mathrm{Sn} / \mathrm{t}$ of tinplate in 1984 (fig. 17). Without a doubt, this reduction was also a consequence of the price policy of the International Tin Council, which maintained artificially high prices over much too long a period, as has been mentioned before. The more expensive a raw material is, the stronger is the incentive to save it. This interpretation is supported by the constant specific consumption of tin in the Western World after the decline of the price of tin in 1985 (fig. 17). In the United States, even a further increase in use can be observed.

- Technological developments helped the German electronic industry to consume as little as $11 \mathrm{t}$ of palladium in 1984. This represents a saving of $2.5 \mathrm{t}$ on the palladium that additionally would have been consumed by using the now-obsolete technology (BGR/DIW/ITE, 1986).

- Another very impressive example is the trend in both the aircraft and automobile industries for using increasingly lightweight com- 


\section{YEAR}

McDonnell Douglas Airbus Industries
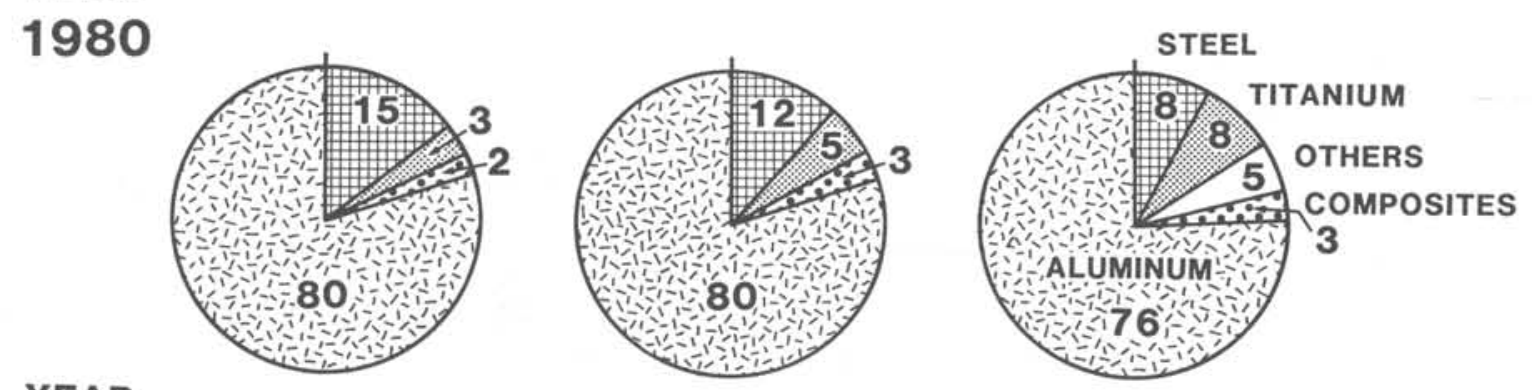

2000
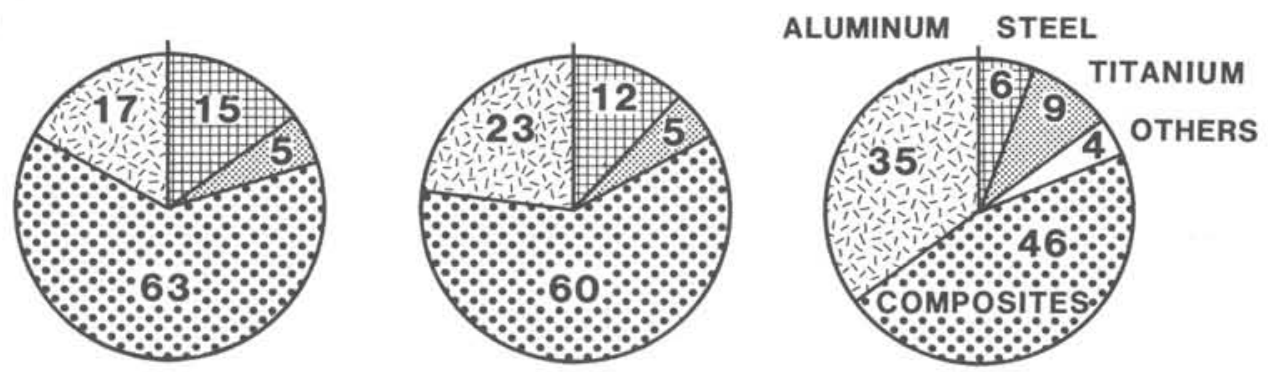

Figure 18. - Comparison of materials used in the aircraft industries in 1980 and the projection for 2000 (sources: Messerschmidt-Bölkow-Blohm (MBB), written communication, 1985; and Sames, 1986). Numbers given are percentages.

1980

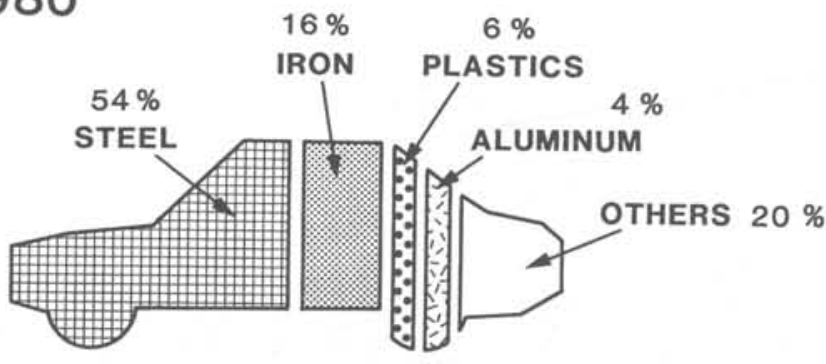

Net weight : $1497 \mathrm{~kg}$

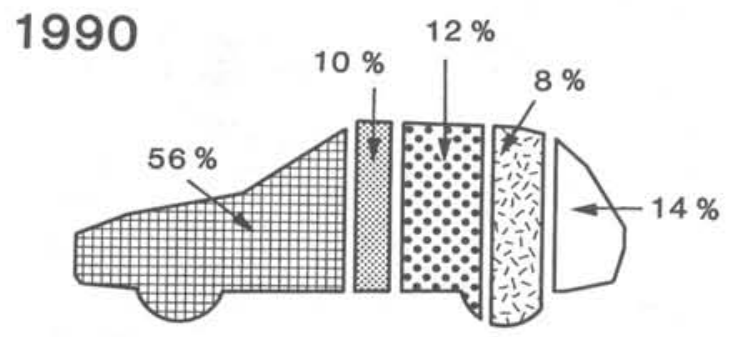

Net weight : $1134 \mathrm{~kg}$

Figure 19.-Comparison of materials used in the automobile industry in 1980 and 1990 (sources: Black and others, 1980; and Sames, 1986). ponents that achieve a saving not only of material but also of energy (figs. 18 and 19).

In short, it is almost impossible to overestimate human ingenuity.

In the past, popular opinion often has had a bleak and desperate outlook on the future of mineral resources, and the best known advocate of this view was the Club of Rome (Meadows and others, 1972). Today we are experiencing a swing of the pendulum in the opposite direction, and again there appears to be an overreaction. However, it is not true that the supply of raw materials will never run into problems, as some people tell us today. We cannot allow ourselves to become complacent. Mined out deposits have to be replaced in order to ensure a supply of essential, primary raw materials. Cost and energy limits apply to the amount of materials that can be recycled. Primary materials, therefore, always will be needed.

Geoscientists have an obligation to tell society that earth resources do exist in large amounts and that it is chiefly the demand and the attainable price that dictate when economic use can be made of them. The geoscientist's message should not be a doomsday prophecy, nor should it be an attitude of "there will never be a problem." We should be confident of the availability of earth resources, and at the same time, we should put our trust in human ingenuity to make use of the riches with which nature has endowed us. This requires sufficient encouragement of basic and applied research and developmenteither through market forces or through public-sector endowment of basic and precompetitive research-on problems of a longer run nature that are not accounted for effectively by market forces. 


\section{Acknowledgments}

The authors wish to express their gratitude to Dr. Helmut Schmidt and Mr. Hermann Kästner for their valuable support.

\section{References}

BGR/DIW/TTE (Bundesanstalt für Geowissenschaften und Rohstoffe, Deutsches Institut für Wirtschaftsforschung und Institut zur Erforschung technologischer Entwicklungslinien), 1986, Versorgungslage bei Rohstoffen: Berlin, Hamburg, Hannover, BGR/DIW/ITE, 193 p.

Black, I.G., Callahan, J.M., and George, J.M., 1980, Metals outlook: Chilton's Automotive Industries, July, p. 28-30.

Humphreys, D., 1982, A mineral commodity life cycle? Relationships between production, price and economic resources: Resources Policy, v. 8 . p. $215-229$.

Malenbaum, W.. 1978, World demand for raw materials in 1985 and 2000: New York, E/MJ Mining Information Services, $126 \mathrm{p}$.

McKelvey, V.E., 1972, Mineral resource estimates and public policy: American Scientist, v. 60, p. 32-40.

Meadows, P.H., Meadows, P.L., Randers, J., and Behrens, W.W., III, 1974. The limits to growth: A report for the Club of Rome's Project in the Predicament of Mankind (2nd edition): New York, Universe Books, $176 \mathrm{p}$.

Metallgesellschaft AG (Aktiengesellschaft), various years, Metal statistics: Frankfurt, Metallgesellschaft AG.

RWI (Rheinisch-Westfälisches Institut für Wirtschaftsforschung, Essen), 1985, Zusammenhang zwischen Wirtschaftswachstum und Stahlverbrauch besteht doch.: Stahl und Eisen, v. 105, no. 21, p. 1117-1118.

Sames, C.W., 1986, Anaconda-Berichte aus der Rohstoffwelt: München, Wirtschaftsverlag Langer-Müller/Herbig, 363 p.

The Economist Intelligence Unit, 1992, World commodity outlook 1992: London. The Economist Intelligence Unit, p. 35.

U.S. Bureau of Mines, various years, Minerals yearbook: Washington, D.C., U.S. Government Printing Office, v. 1.

World Tin, 1990, Thinner tin coatings on tinplate: World Tin, v. 1 (quoted from Tägliche Nachrichten, Metallgesellschaft AG, February 1990). $\square$

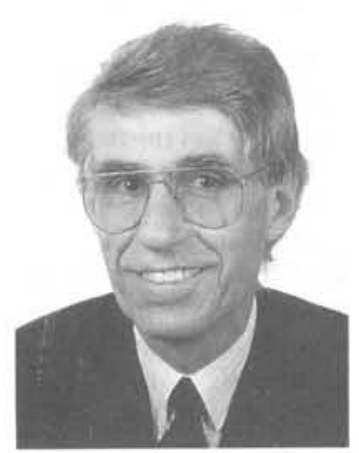

Dr. Friedrich-Wilhelm Wellmer (Head, Division of Economic Geology and International Cooperation. Bundesanstalt für Geowissenschaften und Rohstoffe (BGR)) took his undergraduate studies in geology and mining at the Technical Universities of Berlin and Clausthal and received his doctorate from the Technical University Clausthal. In the past 20 years, Dr. Wellmer has been extensively involved in exploration for base and precious metals for the German company Metallgesellschaft $A G$ in Austria, Ireland, Canada, Australia, Brazil, Chile, Peru, and Bolivia. He assumed his present position in 1987 and has maintained teaching assignments at the Technical University of Berlin in the field of raw material politics and economics. He is the author of many papers and books in the field of mineral exploration, mineral economics, and geostatistics.

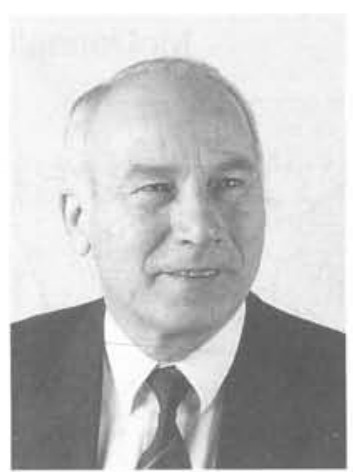

Dr. Martin Kürsten (President, $B G R$ ) was educated at the University of Edinburgh. Scotland. Since 1958, he had been in the service of the Government of the Federal Republic of Germany (FRG) as a mining and exploration geologist and has specialized in iron, copper, and salt deposits. He has acquired extensive international experience through his work in Indonesia, Tanzania, Ethiopia, and Iran and through his responsibilities for all of the overseas projects of BGR from 1979 to 1985 . During this period, his interests were directed toward the formation of geological surveys in developing countries and international geoscientific cooperation. Dr. Kürsten also has served as Professor of Geology at Würzburg University, FRG, and has held his present position since 1986.

\section{NEED TO MATCH SCALES ACCURATELY?}

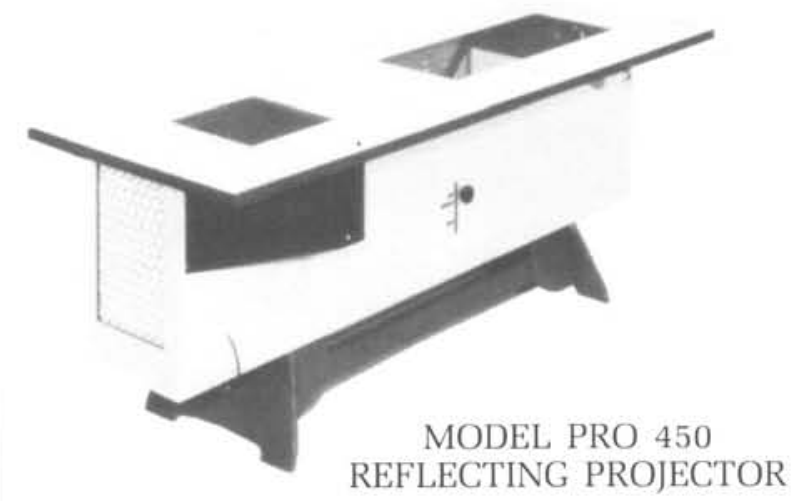

- Finest quality Optics

- Motorized controls

- 1st Surface mirrors

- 4.5X Enlargement to $.22 X$ Reduction

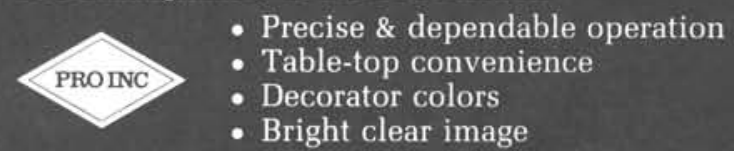

For a well crafted projector, at a reasonable price, with fast delivery, please write or phone:

\section{PROJECTORS INC.}

1523 Tennyson St.

\section{Phone: $303 / 572-8875$}

